\title{
QUARTERLY ANALYSIS: \\ The Progress of Monetary, Banking and Payment System \\ Quarter IV - 2011
}

\author{
Author Team of Quarterly Report, Bank Indonesia
}

The Board of Governor Meeting of Bank Indonesia today decided to maintain the BI rate at the level of $6.0 \%$. This decision is based on thoroughly examination on the recent economic performance, several recent risks, and the prospect of the economy. The Board of Governor view the level of $\mathrm{BI}$ rate is consistent with the targeted inflation ahead, and is conducive to maintain the financial stability, and also to mitigate the impact of global prospect on Indonesian economy.

In general, the evaluation of the performance and the prospect of Indonesian economy show the domestic economy remain strong and stable. Looking ahead, the Board of Governor will keep examining the risk of global economic worsening, maintain the macroeconomic and financial system stability, and stimulate the domestic economy. Board of Governor emphasize the mix of monetary and the other micro prudential policies, which is counter cyclical, is necessary on macroeconomic management and drive the actual inflation to the target of $4,5 \% \pm 1 \%$ in 2012 and 2013.

Board of Governor noted the economy in 2011 was slowing down, mainly due to the uncertainty of economic and financial recovery in Europe and United States. The crisis escalation in Europe particularly on second semester 2011 triggered a high volatility in global financial market. With the reduction of global demand, the global trade volume and commodity price also decreased.

On price side, the inflation pressure in developed countries increased, while in emerging countries is moderate though still in high level. Along with this progress, by the end of 2011, the emerging market tended to choose neutral or slightly accommodative, while the developing countries maintained the accommodative monetary policy with liquidity easing.

On domestic side, the Board of Governor considered the economic performance in 2011 was still strong. This achievement is supported by the maintained macro and financial system stability. The economic growth in quarter IV 2011 is expected to be $6.5 \%$; hence the economic growth in 2011 will be 6.5\% (yoy). This growth is mainly triggered by the strong domestic demand and the maintained export performance. From production side, the main pro-growth sectors are Manufacture, Transport and Telecommunication and Hotel, Trade and Restaurant. 
The performance of Indonesian Balance of Payment (BOP) for the whole 2011 recorded large surplus, even though there was a pressure on semester II, 2011. The pressure was on the capital and financial transaction, along with the increase of global economic and financial market uncertainty.

Several policies of Bank Indonesia and government have helped to restrain the pressure on Rupiah exchange rate. During 2011, the trend is till consistent with the regional exchange rate movement. Bank Indonesia keep monitoring the dynamics of Rupiah and its stability and make sure it moves along with its fundamental.

On price side, the inflation decrease in 2011. CPI inflation on November 2011 was recorded $0.034 \%$ ( $\mathrm{mtm}$ ) or $4.15 \%$ (yoy). The decline of inflation during 2011 occurred due to correction on volatile food prices inflation and minimum administered price inflation, while the core inflation tended to be moderate. The low of volatile food price inflation was supported by the well maintained supplies, either from domestic or import. Even though the rice recorded quite high inflation, there were major price corrections on seasoning such as onion, red chili and on the meat.

Meanwhile, the well-controlled inflation was supported by the sharp declining of the global commodity prices, the stability of exchange rate and a better inflation expectation. If the decline inflation continues, the overall CPI inflation for 2011 is expected to be lower than $4.0 \%$.

The stability of banking system is well maintained with better intermediation function, even there was fluctuation on financial market because of the global influence. Banking industry is solid as reflected on high capital sufficiency (CAR, Capital Adequacy Ratio); way above the required minimum level of $8 \%$, and also reflected on the maintained gross Non-Performing Loan (NPL) of below 5\%. Meanwhile, the loan growth until the end of October 2011 reached $25.7 \%$ (yoy), consisting of investment loan by $31.1 \%$ (yoy), working capital loan $24.7 \%$ (yoy), and consumption loan $23.8 \%$ (yoy). With these progresses, the growth of loan for the whole 2011 will accord the Bank Business Plan.

The reliability and efficiency of payment system support the stability of financial system. As supporting infrastructure for economic activities, the payment system ensures the payment transaction of all economic agents. The supports of the payment system on the economic performances are reflected by several Bank Indonesia policies, including the standardized chip based ATM/debit card, the improvement of card payment system, the development of Bank Indonesia Real Time Gross Settlement (BI-RTGS), the second generation of Bank Indonesia Scrip less Security Settlement System (BI-SSSS), the development of National Payment GatewayNPG, the increase of government account management, and the preparation of standardized electronic money. 
Looking ahead, the global economic growth is expected to slow down due to the high uncertainty of debt and fiscal settlement in Europe and US. This global slowing down will affect the domestic economy growth in 2012 to be around 6.3\% - 6.7\%. For 2013, the growth is expected to be in the range of $6.4 \%-6.8 \%$, along with the global economic improvement. On price side, the Board of Governor predicts the inflation in 2012 and 2013 can be directed to the target of $4.5 \% \pm 1 \%$.

Related to this, the reduction of $\mathrm{BI}$ rate, which has been done so far, is expected to stimulate the economy. The Board of Governor is aware of several risks impact on the macroeconomic balances, including the worsening of global economy. Along with this, beside continuing the monetary and financial system stabilization by ensuring the sufficiency of Rupiah liquidity and foreign exchange on the market, Bank Indonesia will keep optimize the momentum of interest rate decline to optimize the effectiveness of stimulus on the economy. In addition, Bank Indonesia continues and strengthens to coordinate with the government in order to increase the stimulus from fiscal and the real sector. 